\title{
New Industrialization in Serbia - Reality or Delusion
}

UDC: $330.341 .424(497.11)$

DOI: 10.7595/management.fon.2014.0005

SPIN' 13, Belgrade, 05-06. November 2013.

\begin{abstract}
The crucial question demanding answer is why are we once again focusing on industrialization as a strategic goal in a situation of global economic crisis, and in the perspective of the recovery of Serbian economy? In this discussion paper the difficulties that Serbian economy is facing are analyzed having in mind the historical perspective encompassing different social, political and economic circumstances and changes that Serbia underwent in the period after the Second World War. In this overall historical perspective, the development of industry and its overall effects on economic development in Serbia are analyzed. The prospects and economic effects to be expected from new industrialization policy measures are discussed.
\end{abstract}

Keywords: industrialization, development, exports, production, employment

\section{Industrial development in Serbia - a historical perspective}

The focus on new industrialization policy and strategy as the new goal of Serbian economy has emerged and become more explicit in the public -scientific/academic, government and industrial domains. The reasons are to be found in the following arguments:

- The greatest pace of economic development in Serbia was achieved in the period of industrialization after the Second World War;

- Industrialization has proved to be the most efficient method of economic development;

- Industrialization has been used as the dominant strategy in the majority of countries in the world to achieve intensive development;

- The transition model that has been used in Serbia has proved to be a complete disaster.

These arguments deserve special attention and on this occasion I will comment briefly on each of them.

The effects of postwar industrialization - until the disintegration of the Socialist Federal Republic of Yugoslavia (SFRY) in 1990.

In the postwar period, it can be concluded, Serbia was categorized as a medium developed industrial economy, according to the rankings of the OECD and other international criteria placing economies into categories of underdeveloped, medium developed and developed ones.

The rate of industrial development in the period $1955-1990$ was $7.7 \%$ which was and still is an extremely high rate. Nowadays this high rate of development, characterized by some authors as 'accelerated development rate', is accomplished by newly emerging economies (Brazil, India, South Korea, China, Russia) who have never abandoned the goal of enforcing industrial production and mastering increasingly sophisticated technology and operations in creating goods and services.

In 1990, the overall industrial production had risen 11.4 times in comparison to the level recorded in 1955, which clearly points to the increasingly rising industrial capacity in the 35 year period. The total exports that amounted to 5.8 billion dollars, were realized with a $95 \%$ participation of industrial products. At that time Serbia had 1.1 million of industrial workers and the share of industry in the GDP amounted to $44.5 \%$. At that time, many towns in Serbia developed to become important industrial centers and they represented the bearers of an overall social and economic development. 


\subsection{Effects of postwar industrialization, period 1991-2000.}

This difficult decade was designated by disintegration of the country, economic sanctions, bombardment that brought destruction and demolition to the country. All this had negative effects on people, material goods and natural resources, and these effects are still present and will influence the economy and our lives for decades to come.

In the period 1991-2000 the development rate was negative, $-6.6 \%$. In the year 2000 , the increase of industrial production in comparison to the year 1955 was 5 times. With exports amounting to 1.6 billion dollars in 2000 , the share of industrial production was noted to be $29 \%$ of the GDP. The number of industrial workers fell to 765 thousand, which meant it had lost roughly about one third of industrial workers in just ten years. All the industrial centres registered in bigger towns in Serbia suffered deep economic crisis.

In this period all economic indicators showed a drastic fall and decline, with deep social, political and economic discontent and turmoil rising.

\subsection{The second phase of transition: the 'post-October industrialization' period, from 2001}

The events of 2001 have brought radical change, it all began with big promises and even greater expectations at all levels of the economy and society. Looking at 'hard' indicators of economic activity and development in this period, it can be concluded that the decreasing, falling trends of the previous decade are persistent and some show a tendency to accelerated decline.

The rate of industrial production in the period $2000-2011$ was as low as $0.7 \%$. In comparison with the year 1955, industrial production had risen 5.4 times in 2011. The number of industrial workers in 2013 had fallen to 275 thousand, equal to the number of industrial workers that were registered in 1955. The share of industry in the GDP for 2010 had fallen to $18.1 \%$ and to $44 \%$ of the industrial production registered in 1990 .

Industrial production had more than halved in the period of two decades, from 1990 to 2010. The previous industrial centers of Serbia have become the 'dark, black holes' of development in Serbia.

In Table 1 the effects of deindustrialization are presented by the number of workers in industrial centres of Serbia in the years 1990 and 2007, respectively.

Table 1. Effects of deindustrialization by industrial centres and number of industrial workers in 1990 and 2007.

\begin{tabular}{|l|c|c|}
\hline \multirow{2}{*}{$\begin{array}{l}\text { Year } \Rightarrow \\
\text { Industrial centers } \downarrow\end{array}$} & $\mathbf{2}$ Industrial workers \\
\cline { 2 - 3 } & 245390 & $\mathbf{2 0 0 7}$ \\
\hline Beograd & 57574 & 13842 \\
\hline Kragujevac & 25285 & 8331 \\
\hline Niš & 24848 & 3358 \\
\hline Novi Sad & 23378 & 5512 \\
\hline Kruševac & 20357 & 3653 \\
\hline Vranje & 16130 & 6907 \\
\hline Subotica & 13362 & 2374 \\
\hline Pirot & $\mathbf{4 2 6 3 2 4}$ & 2126 \\
\hline Total & \multicolumn{2}{|c|}{$\mathbf{4 6 1 0 3}$} \\
\hline
\end{tabular}

The example of a well known Serbian company for agro-industrial machines "Zmaj" from Zemun provides evidence, at a micro level, of the devastation of the industrial sector. In "ex-Yugoslavia", 95\% of the harvest was processed by combines of Zmaj. In the 1980s, about 5, 000 workers were employed in this company, while by 2012 only 49 were still employed.

In the 1970s, 1200 combines were produced per year, while in 2005 only 34, and from 2007, there has been no production. On the 18 hectares of land where the industrial company Zmaj was situated today we have trade companies DIS, Djak, Vitorog and Dalas. 


\section{The significance of industrial development}

The development of national economies in the nineteenth and twentieth centuries provides evidence that industrial development affects different aspects and spheres of economic and social life. Figures show that the overall living standard has risen immensely and this is one of the main accomplishments directly related to industrial developments.

Also, the industrial and overall structure of the economy has undergone deep change and there is an overall and steep rise of economic development indicators. Industrial development has been shown to materialize comparative and competitive advantages of nations while enabling a dynamic growth of employment, labour productivity and efficiency of all the inputs engaged in industrial production. This leads to technological developments, intensive innovation and major new technological breakthroughs. Dynamic development is observed in all the other sectors as well, with spill-over effects and as a result of high growth in the core industrial sectors. Agriculture is often cited as the very obvious example of such growth.

The structure and trade relations are changing and the exports increase providing steady and healthy grounds for future economic development. Having in mind the complex positive effects of industrial development, it can be concluded that it is in industrial and technological progress that we have found the key to the overall rise of civilization level of societies.

More than ten years ago, in 2000 , at the EU summit in Lisbon, it was concluded that "...the EU had committed a major mistake in the previous period... by not directing the attention of policy makers towards maintaining a strong industry, but had been oriented on the widespread opinion that modern economies are today more based on the service sector and that the industry does not play a crucial role any more..."

The evidence from numerous countries and economies, such as Japan, South Korea and before those, the Check Republic, Slovakia, and especially China, confirm the significance of industrial development in achieving amazing results in economic growth. It should also be noted that Germany has, thanks to efficient industrial development, gone through the period of the latest global economic crisis with the least damage and more lightly than the rest of the West world countries. The opposite is true for Great Britain who has traditionally been the cradle of industrial development and today is facing economic problems much affected by the economic crisis.

\section{What went wrong with the Serbian model of development?}

Some of the reasons why the model of economic development in Serbia in the last decades of transition has failed to provide the planned and expected results could be listed as follows:

- The model was based on the ineffective grounds of the neo-liberal concept of development;

- Macro-economic stability, based on low inflation and stable foreign exchange rate, has become a goal on its own, per se, instead of being a means to enable higher goals of economic effectiveness;

- Instead of introducing incentives for more savings, rise of production and exports, the focus of development policies was on the consumption, rise of services and enormous imports.

\subsection{The main features of Serbian development model}

The main characteristics of the economic model of development in Serbia is that it is basically oriented towards the dependence on direct foreign capital and investments that will enable revival and growth of the GDP. Besides, it is the service sector that is given priority and very modest achievements have been made in the real sector, growth rates of industry and agriculture are lagging behind.

The main impulse for the rise of the GDP was placed on enormous imports which amounted to 113 billion euros in the period 2001-2011. The enormous amounts of imported goods had to be transported, insured, sold and money had to be found for these transactions. These sectors were the fastest growing in the previous period, 2-3 times faster than the GDP growth. Special attention should be paid to the significance of the Added Value Tax on imported goods that provided the state with lavish and stable influx to the state budget. 
This model was kept alive and gave results because it a enabled constant and sufficient influx of foreign capital. In the period 2001-2011, an influx of 115 billion euros has been registered, without taking into account the capital obtained by privatization. The structure of this foreign capital influx is as follows:

- 14 billion euros - net external debt growth

- 29 billion euros - money orders

- 15 billion euros - FDI

- 3 billion euros - donations

- 54 billion euros - exports.

The policy of strong domestic currency, dinar, dominated and in the period 2002-2011 the euro rose by $74.3 \%$, while the total rise of prices amounted to $142.1 \%$.

This model of strong dinar in a weak economy brought benefits to importers, the state, but also to a rising number of people that quickly and without caution took loans and credits becoming more and more indebted.

The overall effects of such a model could be listed in summary as follows:

- Constantly high foreign trade deficit;

- Growth of public and external debt;

- Growth of fiscal deficit;

- Unemployment growth;

- Economic structure disbalance - the share of industry in the GDP was only $18.1 \%$ in 2011 ;

- GDP in 2011 was only $72 \%$ of the GDP level registered in 1990.

In this period a total devastation of the industry in Serbia took place and it can be stated that it started with sanctions and wars, and concluded with transition based on a fatal concept of privatization.

The level of industrial production in 2011 amounted only to $44 \%$ of the level registered in 1990 .

\subsection{Which model should we choose?}

Having in mind the accumulated problems in the economy and a decreased influx of foreign investments, it is the author's opinion that one of the main pillars for future economic growth should be in export oriented industrialization. It is the path that will bring:

- increase and growth of production (and GDP),

- increase in employment

- increase in exports

- and this will enable:

- decrease in foreign trade and fiscal deficits, and

- capability of servicing the fast growing public debt.

The expected effects of the new model of development are the following:

- restructurring of the economy,

- increase in labour productivity,

- increase in exports and balancing of foreign trade,

- rise in employment,

- intensive scientific and technological progress,

- dynamic development of other sectors, especially agriculture.

The main paths of industrial developoment in the next period should be oriented at specific development in: - the energy sector enabling self-sufficiency,

- traditional labour-intensive industry, with ownership restructuring and technological modernization and specifically with loan arrangements and unique products in smaller batches,

- ferrous and non-ferrous metallurgy - modernization and greater product finalization,

- agroindustry development - a comparative advantage of Serbia; in order to become a competitive advantage as well, it deserves more consideration, higher investments and less uncertainty,

- chemical industry with higher levels of processing, finding strategic partners, 
- automobile and electric power industry - represent a very promising opportunity but strategic partnerships are necessary for future development,

- firms in restructuring - limited capacity for growth, the opportunity lies in production based on middle and low level technologies where extremely large batches are not necessary.

There are serious problems in how the development priorities were determined in the previous periods. Different interests (of individuals, political parties) dominated which is obvious from the listed 16 national priorities among which 6 sectors do not belong to industry (i.e agriculture, infrastructure, transport and logistics, tourism, civil engineering and pro-aging). Also there is a vivid mix and misunderstanding concernig what represents a sector, field, branch or a group.

The proiorities should be set at the level of products and based on their comparative and competitive advantage assessment with detailed analysis of demand for these products on world markets. The set of priorities established in such a way are to enjoy state support which means that the state should conduct an industrial policy.

The new industrial policy should be based on a selective approach making use of the following instruments:

- accelerated amortization,

- investment subsidies,

- investment reserves,

- fiscal loans (credits) and fiscal policy in the function of more FDI, especially oriented towards exports and employment growth,

- deducting reinvested profits from taxes,

- support, incentives for foreign investment,

- monetary and credit policy,

- customs protection,

- foreign exchange rate, with special emphasis on realistic foreign exchange rate and keeping in mind that exports are more profitable than imports,

- stimulations and incentives for new technology and innovation with the goal of structural change of the economy and intensive growth,

- intellectual property oriented towards environment protection and international standardization,

- the highest priority should be given to firms with production, exports and employment with moderate protection of export oriented and production ventures bringing new employment.

\section{Concluding remarks on immediate measures}

Among the urgent measures that are to be taken immediately in order to make a turnaround towards industrial development, we see the necessity to establish a separate Ministry for industry to limplement change and to deal with the specific industrial policy and strategies. It is in line with the necessity to develop the Operational plan for industrial recovery with goals, instruments and measures for realization. Cutting costs in all the spheres should be part of this plan, savings wherever possible and cutting down state administration is among the priorities. Simultaneously, it should be noted that investments are not costs and there is no progress without investing.

The creating of healthy business environment should be among the top priority measures comprising cheap and efficient state, modern and unambiguous regulations, efficient implementation of laws equal for all, significantly smaller and more efficient state administration.

It would be highly recommended to form a Development bank with the main goal to enable high quality and adequate sources for financing production, exports and employment.

Having in mind all that has been said, it would be important to start with the realization of the concept of programmed depreciation of national currency, enabling production and exports to become more attractive and profitable in comparison to imports and realization on the domestic market.

Within these efforts, state subsidies should be denied to public firms and firms with losses, and the policy of state support for producers and exporters should be based on principles already used in South Korea some decades ago. 
There should be a detailed analysis of natural comparative advantages in Serbia (one example is food production), with a detailed analysis of world demand for those products in the period to come. With this evidence based approach we should decide what would be the products to receive support within the Industrial policy of Serbia. In an effort to focus on these products and sectors we should concentrate all our means and creative capacities.

Finally, there should be an overall understanding and consensus around these questions especially in the domain of an overall understanding that the new industry would represent a relevant pillar for future social and economic development. These decisions are not easy to implement since it is a common fact that it is easier to deal with services than to produce new value. It is well known that industrial policy will bring payoff in the long run, while short-termed profits and benefits are always more attractive.

In conclusion, new industrial policy and development is the only sustainable path for the future development of Serbia.

\section{REFERENCES:}

[1] Commission of the European Communities, Com (2002) 714 Final, Communication From the Commission to The Council, The European Parliament, the Economic and Social Committee and The Committee of The Regions, Industrial Policy in an Enlarged Europe, Brussels, 11.12.2002.

[2] Dimitrijević, Bojan, \uričin, Dragan, \urić, Draginja, Grujić, Branislav, Perčević, Goran, Spasojević, Toplica, Nacrt strategije reindustrijalizacije Srbije, radna grupa za reindustrijalizaciju Nacionalnog saveta za privredni oporavak, Beograd, 2013. godine

[3] European Council, Conclusions, Brussels, 17 June 2010.

[4] http://ec.europa.eu/eu2020/pdf/council_conclusion_17_june_en.pdf (25.11.2013.)

[5] Narodna banka Srbije, Platni bilans Republike Srbije 2001-2012, Beograd, 2013, http://www.nbs.rs/internet/cirilica/80/platni_bilans.html (03.12.2013)

[6] Republika Srbija, Ministarstvo ekonomije i regionalnog razvoja, Republički zavod za razvoj, Strategija i politika razvoja industrije Republike Srbije 2011-2020, (Predlog), Beograd, 2011.godine

[7] Republika Srbija, Ministarstvo finansija, Bilten javnih finansija, Beograd, avgust 2013.godine

[8] Rodrik, Dani, Industrial policies for the Twentx-First Century, Harvard University, 2004.

[9] Savić, Ljubodrag, Ekonomika industrije - 8. izd. Beograd, CID, Ekonomski fakultet, 2013.godine

[10] Savić, Ljubodrag, Industrijalizacija - mit ili stvarnost, Politika, 29. novembar 2013, Beograd

[11] Savić, Ljubodrag, Srpska industrijalizacija za dvadeset prvi vek, Industrija, 1/2009, Ekonomski institut, Beograd, 2009. godina

[12] Savić, Ljubodrag, Tranzicija srpske privrede - kriza razvoja industrije, Beograd, CID, Ekonomski fakultet, 2008.godine

[13] Službeni glasnik RS, br. 54/10, Uredba o klasifikaciji delatnosti, Beograd, 2013, http://webrzs.stat.gov.rs/WebSite/Public/PageView.aspx?pKey $=412$

[14] World Bank, World Development Reports, 2013., http://data.worldbank.org/indicator/NV.IND.TOTL.ZS

Receieved: November 2013. Accepted: March 2014.
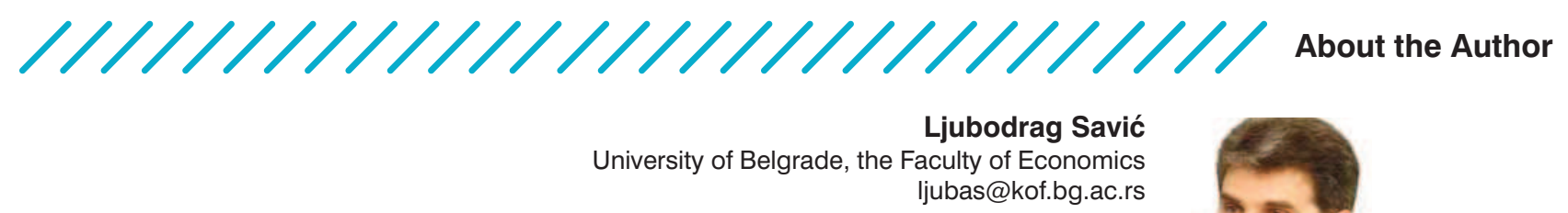

Born in Tripkovo, near Cajetina, in 1955. Graduated from the Faculty of Economics, Belgrade in 1980. Got the MSc degree in 1985, and the PhD degree in 1992. Has been teaching at the Faculty of Economics since 1981. Married, three children. Teaching commitments: Economics of industry. Gave lectures in Scientific and technological

progress. Research interests: Industrial policy. Other professional activities: Manager of several projects on capital evaluation in the Centre for evaluation and auditing within NICEF - Scientific and research centre of the Faculty of Economics.

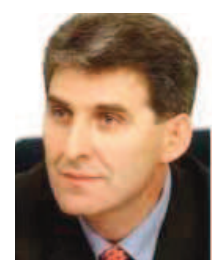

